\title{
Molecular Characteristics of Batanghari, Tambago, Orange, and Mandiangin Giant Gourami Strains
}

\author{
${ }^{\square}$ Agus Nuryanto, Anatasia Endang Pulungsari \\ DOI: 10.15294/biosaintifika.v9i3.12097 \\ Faculty of Biology, Universitas Jenderal Soedirman, Indonesia
}

\section{History Article}

Received 18 August 2017 Approved 30 November 2017 Published 31 December 2017

\section{Keywords} diversity; Neighbor-joining; Osphronemus goramy
Genetic distances; Genetic

\begin{abstract}
Morphological variations among geographic and can be identified as different species. However, a lot of studies proved that morphological variations are also common in conspecific individuals. Therefore, precise identification using additional characters is vital, such as using a molecular marker. Here, we characterized Batanghari, Tambago, Orange, and Mandiangin gourami strains using the cytochrome $b$ gene to evaluate their taxonomic status. Partial sequences of cytochrome $b$ gene were sequenced for 40 individuals. Taxonomic status was checked for giant gourami sequences available in GenBank. Kimura 2-Parameter genetic distances were calculated in MEGA6 software. Haplotype and nucleotide diversity within population and $\Phi_{\text {st }}$-value among populations were estimated in Arlequin software. Phylogenetic relationship was reconstructed using the neighbor-joining method in MEGA6 software based on Kimura 2-parameter model with 1000 pseudobootstraps. Taxonomic identification results in $99 \%$ sequences homology to Osphronemus goramy sequences (accession number KU984978.1 and AY763768.1), means that all strains belong to single species. Low genetic distances, medium haplotype and low-level nucleotide diversity were observed among strains. Pairwise $\Phi_{\text {st }}$-comparison indicates no genetic differences among Sumatera strain, whereas strong genetic structures observed between Sumatera and Mandiangin strains. The phylogenetic tree showed that Mandiangin formed separate subclades from other strains with bootstraps value of $100 \%$. This finding has important implication for breeding sciences and efforts.
\end{abstract}

\section{How to Cite}

Nuryanto, A., \& Pulungsari, A. E. (2017). Molecular Characteristics of Batanghari, Tambago, Orange, and Mandiangin Giant Gourami Strains. Biosaintifika: Journal of Biology \& Biology Education, 9(3), 592-599.

(C) 2017 Universitas Negeri Semarang

Correspondence Author:

J1. Dr. Soeparno 63 Purwokerto 53122

p-ISSN 2085-191X

E-mail: anuryanto2003@yahoo.com 


\section{INTRODUCTION}

Giant gourami (Osprhronemus gouramy Lac.) is an indigenous freshwater fish species in Indonesia. Geographic distribution of this species in Indonesia includes Java, Sumatera, and Kalimantan (Froese and Paulin, 2017). Geographic distribution might lead to geographic isolation among geographic populations which might cause speciation (Losos and Glor, 2003). In case of geographic distribution of giant gourami, it leads to the emergence of geographic strains, such as Soang, Jepang, Paris, Bastar, and Porcelain (Setijaningsih et al., 2007), Batanghari in Jambi (Nugroho, 2011), Tambago and Orange West Sumatera (Nuryanto et al., 2017a).

All the strains showed variable morphological characteristics (Azrita and Siandri, 2015). Morphospecies status of individuals with different morphology is occasionally become difficult to be defined (Heinrichs et al., 2004). However, large amount of studies proved that morphological variations are observed within species in a wide range of animal phyla (Kelley et al., 2011; Hepp et al., 2012). According to Tzeng et al. (2000), morphological variations among geographically separated populations involve their genetic components which are also variable. Flot et al., (2008) had proved a positive correlation between genetic and morphological variations.

Previous studies showed molecular variation among strains (Sari et al., 2014; Nugroho et al., 2013; Nugroho, 2011; Nugroho \& Kusmini, 2006). However, all those studies were used RAPD and Isozyme markers that less precise tools for species identification and mostly done in gourami from Java. So far, no published information on molecular characteristics of giant gourami strains from Sumatera and Kalimantan especially based on partial sequences of cytochrome $\mathrm{b}$ gene. Therefore, it is important to study on a molecular feature of morphologically differences giant gourami strains from Sumatera and Kalimantan based on partial sequence of cytochrome $b$ (cyt b) gene to clarify their taxonomic status whether morphological differences among strains refer to either different species or only pointing out as geographic isolates or subspecies.

Taxonomic status and genetic differences among geographic strains can be evaluated based on their molecular characteristics. Several markers are commonly used in molecular characterization, one of which is partial sequences of cytochrome $b$ gene. This gene has a strong phylogenetic sign and high variation among populations due to its high evolution rates in fish (Tang et al., 2006). It has been proved that cytochrome $\mathrm{b}$ is a useful marker for fish species identification (Griffiths et al., 2010; Perez et al., 2007; Pepe et al., 2005), fish genetic diversity (Perdices et al., 2004), phylogenetic analysis (Tsigenopoulos et al., 2002; Casey et al., 2004; Doadrio dan Dominguez, 2004), and phylogeographic studies (Kotlik dan Berrebi, 2001; Santos et al., 2003). It is expected that the use of the Cyt $b$ gene in giant gourami strains characterization can be used to analyze their genetic diversity and differences and subsequently be used to strengthen the taxonomic status of giant gourami strains from Sumatera and Kalimantan.

This study is expected to provide information which is valuable in developing a breeding strategy within and among strains to obtained high-quality strains and preserve unique characters of each strain.

\section{METHODS}

Tissue samples of caudal fin were collected in May 2016 for Tambago, Orange, (Payakumbuh, West Sumatera) and Batanghari (Jambi) strains, while for Mandiangin strain were collected in April 2017 from Mandiangin (South Kalimantan). Tissue samples were then preserved in the absolute ethanol $96 \%$ and kept in the refrigerator until DNA processing.

Total genomic DNA was extracted using Chelex methods (Walsh et al., 1991) with optimization in incubation times. The fragment of cytochrome $b$ gene was multiplied utilizing a pair of primer as follows; forwards L14725L:5'CGA AAC TAA TGA CTT GAA AAA CCA CCG TTG3' and reverse HMVZ16:5'AAA TAG GAA RTA TCA YTC TGG TTT RAT3' (Santos et al., 2003). A total volume of $50 \mu 1$ of PCR reactions was used during amplification. These mixtures consisted of $33.7 \mu 1$ of ultrapure water (Thermo scientific), $1 \mathrm{X}$ of dream taq buffer (Thermofisher Sciencefitic), $0.4 \mathrm{mM}$ of dNTPs, primer 0.4 picomols of each primer, 1 U DNA Taq polymerase and $2 \mu \mathrm{l}$ DNA template. PCR process was observed in the thermal cycle Peqstar (PeqLab Company). The cycles were performed in the following temperature regime; predenaturation in $95^{\circ} \mathrm{C}$ for 3 minutes and continued with 40 cycles with 30 seconds denaturation in $95^{\circ} \mathrm{C}$, annealing in $45^{\circ} \mathrm{C}$ $+0,1^{\circ} \mathrm{C}$ for 45 seconds, and chain elongation in $72{ }^{\circ} \mathrm{C}$ for 1 minute. Final elongation was done in $72^{\circ} \mathrm{C}$ for 9 minutes. The PCR products were stained with ethidium bromide and migrated in $1 \%$ agarose gel. Afterward, the PCR products were visualized over UV-light transilluminator. 
Partial sequences of the cyt $b$ gene were obtained by submitting qualified PCR products to $1^{\text {st }}$ BASE Asia (www.base.asia.com) for sequencing.

Multiple sequences alignment was done in ClustalW (Thompson et al., 1994) in Bioedit 7.0.5. (Hall, 2005). Species-level identification was conducted by submitting the sequences to GenBank using basic local alignment search tool (BLAST). Nucleotide sequences were translated into amino acid sequences using ORF Finder online version (https://www.ncbi.nlm.nih.gov/ orffinder/) to ensure that the resulted sequence is a functional gene. Haplotype (Nei, 1987) and nucleotide (Nei \& Jin, 1989) diversity were statistically calculated in Arlequin software version 2.0 (Schneider et al., 2000). Overall haplotype and nucleotide diversity were estimated statistically using DnaSP version 4.0 (Rozas et al., 2003). Pairwise $\Phi_{\text {st }}$ comparisons were conducted in Arlequin version 2.0 (Schneider et al., 2000). Kimura 2-Parameter (K2P) genetic distances were calculated using MEGA6 (Tamura et al., 2013). Evolutionary relationships among strain were estimated through phylogenetic tree reconstruction using MEGA 6.0 (Tamura et al., 2013). The phylogenetic tree was reconstructed using a neighbor-joining algorithm with 1000 non-parametric bootstraps. The polarity of branching pattern was obtained through outgroup comparison with Trichopodus pectoralis (accession number AY763758.1) and $T$. trichopterus (AY763759.1) as outgroups taxa.

\section{RESULT AND DISCUSSION}

Partial sequences of the cytochrome $b$ gene were successfully sequenced from 40 individuals of four giant gourami strains. The resulted sequences range from three individuals of Orange strains to 20 individuals of Mandiangin strain. Homology test showed that all strains have sequences similarity of $99 \%$ to previously published sequences of Osphronemus goramy available in GenBank (KU984978.1 99\% dan AY763768.1). This homology test means that all strains belong to Osphronemus goramy Lacepede, 1801. This placement is fulfilled the requirement of similarity among individuals as notes by Pereira et al. (2013) that two or more individuals can be referred to as a single species when they have sequences similarities between $97 \%$ and $100 \%$. Species delineation of all strains to a single species was supported by the low level of K-2P genetic distances among strains (from $0.0 \%$ to $1.1 \%$ ). Our finding is similar to what was reported by Pegg et al. (2006) in other fish groups which observed genetic distan- ce among individuals from single species ranges from $1 \%$ to $3 \%$. This similarity could be due to that we have used a similar genetic marker that was mitochondrial cytochrome genes.

Multiple alignments of the cytochrome $b$ genes from 40 individuals of four giant gourami strains resulted in 357 base pairs (bp) fragments. Seven polymorphic sites were observed among $357 \mathrm{bp}$ fragment from 40 total sequences (1.9\%). This value indicates that the used marker has a low level of polymorphisms. Low genetic polymorphisms were also observed in Myripristis ber$n d t i$ (Craig et al., 2007) and in Ephinepenlus itijara (Craig et al., 2009). This similar result indicates that low level of genetic polymorphisms can be observed in the broad scope of fish species.

Genetic diversity analysis result in haplotype diversity value ranges from 0.533 to 0.714 and nucleotide diversity ranged between 0.001 and 0.003 . Complete data on haplotype and nucleotide diversity are presented in Table 1.

Table 1. Individual number, haplotype number, polymorphic loci, haplotype and nucleotide diversity

\begin{tabular}{lccccc}
\hline Strain & $\mathrm{n}$ & $\begin{array}{c}\text { hap- } \\
\text { lo- } \\
\text { type }\end{array}$ & $\begin{array}{c}\text { Poly- } \\
\text { mor- } \\
\text { phic } \\
\text { loci }\end{array}$ & $\mathrm{h}$ & $\pi$ \\
\hline $\begin{array}{l}\text { Batanghari } \\
\begin{array}{l}\text { Mandian- } \\
\text { gin }\end{array}\end{array}$ & 10 & 2 & 1 & 0.533 & 0.001 \\
$\begin{array}{l}\text { Padang } \\
\text { Tambago }\end{array}$ & 7 & 3 & 7 & 0.684 & 0.003 \\
Orange & 3 & 2 & 1 & 0.667 & 0.002 \\
\hline
\end{tabular}

It can be seen from Table 1 that with the range value of haplotype diversity between 0.533 and 0.714 indicate medium genetic diversity within strain. Medium haplotype diversity values of cyt $b$ gene in our study are similar to what was reported by Craig et al. (2007) in twenty populations of coral reef fish Myripristis berndti ( $h=$ 0.286-0.829) from geographic widely separated populations, and Craig et al. (2009) in goliath grouper Ephinepenlus itijara from Panama, Bezile, Brazil, and Florida populations $(h=0.324-0.684)$. According to our result in giant gourami and those previous studies, it is likely that moderate haplotype diversity is rather common in cyt $b$ gene of fish taxa.

Our result is different to Akbar et al. (2014) study who had reported a high genetic diversity of cytochrome $b$ gene on yellowfins tuna (Thunnus albacares; $h=0.990)$. The difference between 
our results to the study from Akbar et al. (2014) might be caused by two factors. Firstly, it could be due to that mutation rate of the cyt $b$ gene on tuna species are different to that in giant gourami. Secondly, the difference between our study from the study of Akbar et al. (2014) might be caused by the source of populations. In this study, we used cultivated species, while Akbar et al. (2014) used natural populations. It is assumed that cultivated population receives different selection pressure than that natural population. Different selection pressures might cause different adaptive evolution and lead to various genetic diversity level.

The observed nucleotide diversity ranges from 0.001 to 0.003 indicates a low level of haplotype diversity. This result in accordance with Kochzius \& Nuryanto (2008) that nucleotide diversity value less than 0.01 refers to low-level diversity. All genetic parameters indicate that the studied giant gourami strains had low genetic diversity in their cytochrome $b$ gene. Low genetic diversity was also observed in cultivated fish species, such as Carassius carassius (Yoon and Park, 2002) and in sea bream, Sparus aurata (Alarcon et al., 2004).

Amova results in with $\Phi_{\text {st- }}$ value of 0.281 and mean square value of 0.127 . A statistical test of $95 \%$ significance level proved that strong genetic structure occurred among giant gourami strains $(p<0.0001)$. However, when we look carefully to the result of pairwise $\Phi_{\text {st }}$ comparison analysis, only Mandiangin strain that contributes to the observed genetic structure, while Sumatera strains were not genetically different as indicated by the low level of pairwise $\Phi_{\text {st- }}$ values (Table 2 ).

Pairwise $\Phi_{\text {st- }}$ comparison values range from -0.264 between orange and Batanghari strains up to 0.379 between Mandiangin and Batanghari strains. The pairwise $\Phi_{\text {st- }}$ values among strains are presented in Table 2 .

Table 2 showed low levels of genetic differences among Sumatera strains indicated no genetic structure among Sumatera strains. This condition might be caused by high genetic exchanges among strains through seed transfer among areas in Sumatera. In case of Sumatera strains, our study has a similar result to a part of
Craig et al. (2007) study in reef fish Myripristis berndti where no genetic differences were observed in rather narrow areas such as within Central Pacific $\left(\Phi_{\text {st }}=-0.007, \mathrm{p}=0.634\right)$, within Indian Ocean $\left(\Phi_{\text {st }}=-0.027, \mathrm{p}=0.528\right)$, and within the east Pacific $\left(\Phi_{\text {st }}=-0.061, \mathrm{p}=0.920\right)$. The present study and previous study from Craig et al. (2007) indicates low rates of molecular evolution in mitochondrial cytochrome $b$ gene which lead to no genetic structuring among populations in small geographic scales. Therefore, it is not surprising if a low level of genetic differences were observed in cyt $b$ gene among morphologically different giant gourami strains in Sumatera.

Another interesting finding that can be summarized from Table 2 was that high $\Phi_{\text {st- }}$ values were observed between all strains from $\mathrm{Su}$ matera and Mandiangin strain. Those $\Phi_{\text {st }}$ values indicate significant genetic structures or genetic differences were found between Sumatera strains and Mandiangin strain. This condition might be due to no genetic exchange between those two islands because seeds transportation mainly tends to occur on the island. This result was also similar to another part of Craig et al. (2007) and Craig et al. (2009) studies in two reef fish species where significant genetic differences were found among large geographically separated populations. Moreover, strong genetic structures were also observed among geographically separated cyprinids populations (Durand et al., 2002) and among Orizyas latipes populations Takehana et al. (2003). The finding of our study and all previous studies proved that cyt $b$ gene is a suitable marker for genetic structure study in distantly separated populations but not for geographically closed populations.

Molecularly, the Mandiangin strain is differentiated by three transitions in their pyrimidine nucleotide. These shifts were observed in base position of 240 from $\mathrm{T}$ gourami Batanghari, Tambago, and Orange strain to $\mathrm{C}$ in Mandiangin strains. In the nucleotide position of 249 and 279, transitions occurred from C in Batanghari, Tambago and, orange strains become $\mathrm{T}$ in Mandiangin strain. Those changes made Mandiangin strain genetically separated from all other strains

Table 2. Pairwise $\Phi_{\text {st }}$-values among strains

\begin{tabular}{lcccc}
\hline Strain & Batanghari & Mandiangin & Padang Tambago & Padang Oranye \\
\hline Batanghari & - & & & \\
Mandiangin & $0,379^{* * *}$ & - & & \\
Tambago & $-0,086^{\mathrm{ns}}$ & $0,304^{* * *}$ & - & - \\
Orange & $-0,264^{\mathrm{ns}}$ & $0,321^{* *}$ & $-0,215^{\mathrm{ns}}$ & - \\
Keterangan: ${ }^{*}=0.05 \geq p \geq 0.01,{ }^{* *}=0.01>p \geq 0.001,{ }^{* * *}=p<0.001 ;$ ns $=$ not significant
\end{tabular}


from Sumatera. However, since the different between Mandiangin and all other Sumatera's strains were still in the range of species variability. Therefore, they are conspecific strains.

Tree topology supports the results of the pairwise comparison, genetics distances, and amova (Figure 1). It can be inferred from Figure 1 that all giant gourami strains formed a monophyletic group compared to the outgroup species with maximum bootstraps value of 100 . The tree topology proved that all strains are evolved from a single common ancestor. It means that all strains are belonging to single species. The argument was in accordance with the statement from Gill et al. (2005) that group of individuals which are originated from one speciation event or evolved from one ancestor can be delimited single group. In species level, this monophyletic group can be assigned to single species.

If we look into detail in Figure 1, the giant gourami strains were divided into two different subclades (A and B). The subclade A consisted of Batanghari, Tambago, and Orange strains. The subclade B only included Mandiangin strain. This subclade division between Sumatera and Kalimantan strains indicates that giant gourami from those islands showed that significant genetic structure occurred between Sumatera and Kalimantan strain. However, this division did not lead them belong to different species because all the strains were only separated by the short length of branching pattern in a phylogenetic tree with the branch length less than 0.02 (Figure3).

The K-2P genetics distances were range from 0.000 to 0.014 . Complete K-2P genetic distances were presented in Table 3 . These values showed low genetic distances among strains. Low genetic distances in cytochrome $b$ gene among large gourami populations provide data that phenotypic differences were not always positively correlated to differences in molecular level. Therefore, based on low level of genetic distances among Batanghari, Tambago, Orange, and Mandiangin strain can be defined convincingly that all strains are belonging to single species, namely Osphronemus goramy Lacepede, 1801. This was because several studies note that different species can be delineated molecularly into species level if they have minimum genetic divergences of $0.02(2 \%)$ (Barber et al., 2002). A more significant value was reported by Nuryanto et al. (2007) and Nuryanto et al. (2017b), which found genetic divergences among species was higher than $0.05(5 \%)$.

In taxonomy, phenotypic differences among geographically separated individuals from single species are referred as to different ecophenotype. Several studies proved that many animal populations have various ecophenotypic individuals (Langerhans et al., 2003; Zieritz and Aldridge, 2009). Therefore, morphological variations in giant gourami strains from Sumatera and Kalimantan can be referred as to different ecophenotype.

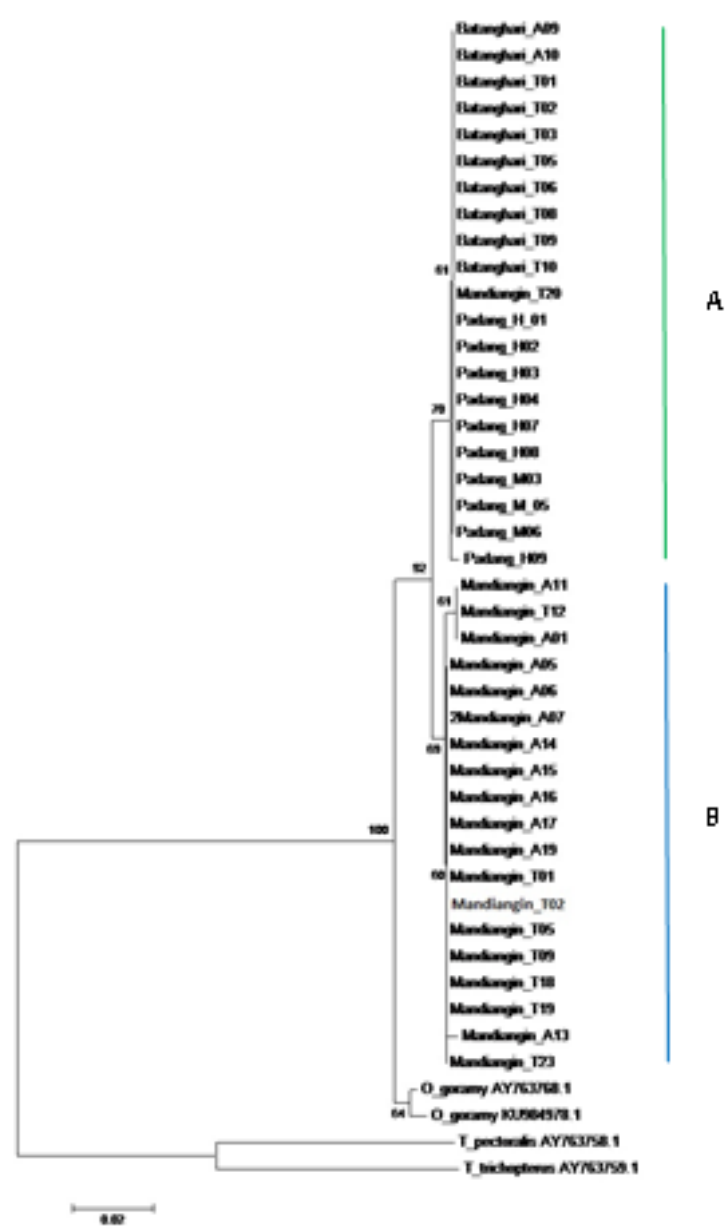

Figure 1. Phylogenetic tree indicates giant gourami strains divided into two subclades (A and B) Remark: The number upper and below the lines are bootstraps values; Clade Sumatera (Batanghari, Tambago, Orange); Clade Kalimantan (Mandiangin)

Our result was different to Santos et al. (2003) study which found high genetic distances in cyt b gene of geographically separated Macrodon ancylodon populations and Craig et al. (2009) which also observed a high genetic difference among goliath grouper (Epinephelus itajara) populations. The differences between our result and the study from Santos et al. (2003) and Craig et al. (2009) might due to we used a different source of populations. In one hand, we used cultivated populations which might be under similar selecti- 
Table 3. The K-2P genetic distances among giant gourami strains

\begin{tabular}{lcccc}
\hline Strain & Batanghari & Mandiangin & Tambago & Orange \\
\hline Batanghari & 0.000 & & & \\
Mandiangin & $0.009-0.011$ & $0.000-0.011$ & & \\
Tambago & $0.000-0.003$ & $0.000-0.014$ & $0.000-0.003$ & \\
Oranye & 0.000 & $0.000-0.011$ & $0.000-0.003$ & 0.000 \\
Trichopodus & $0.215-0.217$ & $0.211-0.217$ & $0.215-0.221$ & $0.215-0.217$ \\
T.Pectoralis vs T.trichopterus $=0.118$ & & \\
\hline
\end{tabular}

on pressure from breeder to develop high-quality strains. This directional selection will cause genetic changes and has an evolutionary impact on those populations and lead to homogenization of gene component of the giant gourami populations. According to Mysterud (2011) and Jorgensen et al. (2007), directional selection might lead to genetic alteration and has a significant impact on the evolutionary success of populations. In case of breeding selection might cause loss of genetic diversity within population, such as in giant gourami strains from Sumatera and Kalimantan. Previous studies proved low genetic diversity in cultivated fish species of Carassius carassius (Yoon $\&$ Park, 2002) and sea bream, Sparus aurata (Alarcon et al., 2004)

Our finding on taxonomic status and molecular characters of giant gourami strains from Sumatera and Kalimantan has necessary implication for the development of giant gourami cultivation, especially for developing high-quality strain. Information from this study is also vital for strains conservation to sustain the variability within each strain as germ plasma for sustainable of giant gourami resources. Our data also showed the importance of fundamental science to support applied science or even culture science and breeding science.

\section{CONCLUSION}

Gant gourami strains from Sumatera are genetically similar, whereas Mandiangin strain from Kalimantan showed significant differences compared to Sumatera strains. All strain formed monophyletic group compared to outgroups species and separated into two subclades in the phylogenetic tree. In general, all strains had low genetic differences. Based on all the analysis, Batanghari, Tambago, Orange, and Mandiangin strains belongs to Osphronemus goramy Lacepede, 1801.

\section{ACKNOWLEDGEMENT}

We would like to thanks to the Directorate Research and Public Services, The Directorate Jenderal Research Strengthening and Development, The Ministry of Research, Technology, and Higher Education for providing the funding through Applied Research Scheme 2017; Research and Public Service Institute of Jenderal Soedirman for administrative support; Head and staff BBPBAT Sigelam Jambi; BBI Sicincin Payakumbuh; and BBAT Mandiangin who provide valuable help during the field trips. Thanks also to students who help during laboratory examination. We also give high appreciation to the reviewer who gave helpful comments and suggestion to raise scientific values of this manuscript.

\section{REFERENCES}

Akbar, N., Zamani, N. P. \& Madduppa, H. H. (2014). Keragaman genetik ikan tuna sirip kuning (Thunnus albacares) dari dua populasi di Laut Maluku, Indonesia. Depik, 3(1), 65-73.

Alarcon, J. A., Magoulas, A., Georgakopoulos, T., Zouros, E., \& Alvarez, M. C. (2004). Genetic comparison of wild and cultivated European populations of the gilthead se bream (Sparus aurata). Aquaculture, 230(1), 65-80.

Azrita \& Syandri, H. (2015). Morphological character among five strains of giant gourami, Oshpronemus Gouramy Lacepede, 1801 (Actinopterygii: Perciformes: Osphronemidae) using a truss morphometric system. International Journal of Fisheries and Aquatic Studies, 2(6), 344-350

Barber, P. H., Palumbi, S. R., Erdmand, M. V., \& Moosa, M. K. (2002). Sharp genetic breaks among populations of Haptosquilla pulchella (Stomatopoda) indicate limits to larval transport: patterns, causes and consequences. Molecular Ecology, 11(4), 659-674.

Casey, S. P., Hall, H. J., Stanley, H. F. \& Vincent, A. C. J. (2004). The origin and evolution of seahorses (genus Hippocampus): a phylogenetic study using the cytochrome $b$ gene of mitochondrial DNA. Molecular Phylogenetics and Evolution, 30(2), 261-272. 
Craig, M. T., Eble, J. A., Bowen, B. W., \& Robertson, D. R. (2007). High genetic connectivity across the Indian and Pacific Oceans in the reef fish Myripristis berndti (Holocentridae). Marine Ecology Progress Series, 334, 245-254.

Craig, M. T., Graham, R. T., Torres, R. A. Hyde, J. R. Freitas, M. O., Ferreira, B. P., Hostim_Silva, M., Gerhardinger, L. C. Bertocini, A. A., \& Robertson, D. R. (2009). How many species of goliath grouper are there? Cryptic genetic divergence in a threatened marine fish and the resurrection of a geopolitical species. Endagered Species Research, 7(3), 167-174.

Doadrio, I. \& Domiguez, O. (2004). Phylogenetic reltionships within the fish family Goodeidae based on cytochrome b sequence data. Molecular Phylogenetics and Evolution, 31(2), 416-430.

Durand, J. D., Tsigenopoulos, C. S., Unlu, E., \& Berrebis, P. (2002). Phylogeny and biogeography of the Family Cyprinidae in the Middle East inferred from cytochrome $b$ DNA-evolutionary significance of this region. Molecular Phylogenetics and Evolution, 22(1), 91-100.

Flot, Jean-Francois, Magalon, H., Cruaud, C., Couloux, A., \& Tillier, S. (2008). Patterns of genetic structure among Hawaiian corals of the genus Pocillopora yield clusters of individuals that are compatible with morphology. Comptes Rendus Biologies, 331(3), 239-247.

Froese, R. \& Pauly, D. Editors. (2017). FishBase. World Wide Web electronic publication. www. fishbase.org, version (06/2017).

Gill, F. B., Slikas, B. \& Sheldon, F. H. (2005). Phylogeny of titmice (Paridaae): II, species relationships based on sequences of the mitochondrial cytochrome-b gene. The Auk, 122(1), 121-143.

Griffiths, A. M., Sims, D. W., Cotterell, S. P., El Nagar, A., Ellis, J. R., Lynghammar, A., McHugh, M., Neat, F. C., Pade, N. G., Queiroz, N., Serra-Pereira, B., Rapp, T., Wearmouth, V. J., \& Genner, M. J. (2010). Molecular markers reveal spatially segregated cryptic species in a critically endangered fish, the common skate (Dipturus batis). Proceedings of the Royal Society B. rspb20092111.

Hall, T. A. (2005). BioEdit: a user-friendly biological sequence alignment editor and analysis program for Windows 95/98/NT/2000/XP. Ibis Therapeutics, A division of Isis Pharmaceuticals 1891 Rutherford Road Carlsbad, CA 92008.

Heinrichs, J., Groth, H., Lindner, M. \& Feldberg, K. (2004). Molecular, Morphological, and Phytochemical Evidence for a Broad Species Concept of Plagiochila bifaria (Hepaticae). The Bryologist, 107(1), 28-40.

Hepp, L. U., Fornel, R., Restello, R. M., Trevisan, A., \& Santos, S. (2012). Intraspecific morphological variation in a freshwater crustacean aegla plana in southern Brazil: effects of geographical isolation on carapace shape. Journal of Crustacean Biology, 34(4), 511-518.
Jørgensen, C., Enberg, K., Erin S. Dunlop, E. S., Arlinghaus, R., Boukal, D. S., Brander, K., Ernande, B., GErdmark, A., Johnston, F., Matsumura, S., Pardoe, H., Raab, K., Silva, A., Vainikka, A., Dieckmann, U., Heino, M., \& Rijnsdorp, A. D. (2007). Managing evolving fish stocks. Science, 318(5854), 1247-1248.

Kelley, A. L., de Rivera, C. E., \& Buckley, B. A. (2011). Intraspecific variation in thermotolerance and morphology of the invasive European green crab, Carcinus maenas, on the west coast of North America. Journal of experimental marine biology and ecology, 409(1), 70-78.

Kochzius, M. \& Nuryanto, A. (2008). Strong genetic population structure in the boring giant clam Tridacna crocea across the Indo-Malay Archipelago: implications related to evolutionary processes and connectivity. Molecular Ecology, 17(17), 3775-3787.

Kotlik, P. \& Berrebi, P. (2001). Phylogeography of the barbael (Barbus barbus) assessed by mitochondrial DNA. Molecular Ecology, 10(9), 2177-2185.

Langerhans, R. B., Layman, C. A., Langerhans, A. K., \& Dewii, T. J. (2003). Habitat-associated morphological divergence in two Neotropical fish species. Biological Journal of the Linnean Society, 80(4), 6989-698.

Losos, J. B. \& Glor, R. E. (2003). Phylogenetic comparative methods and the geography of speciation. TRENDS in Ecology and Evolution, 18(5), 220-227.

Mysterud, A. (2011). Selective harvesting of large mammals: how often does it result in directional selection? Journal of Applied Ecology, 48(4), 827-834.

Nei, M. (1987). Molecular evolutionary genetics. New York: Columbia University Press. 512 pp.

Nei, M. \& Jin, L. (1989). Variances of the average numbers of nucleotide substitutions within and between populations. Molecular Biology and Evolution, 6(3), 290-300.

Nugroho, E., Rahayuni, E., \& Hamid, M.A. (2013). Gurame Batang hari: benarkah strain beerbeda? Satu kajian genetik denganmenggunakan marker DNA. Media Akuakultur, 8(1), 9-12.

Nugroho, E. (2011). Evaluasi variasi genetik ras-ras ikan gurame dengan menggunakan marker DNA. Jurnal Perikanan, 13(2), 86-89.

Nugroho, E. \& Kusmini, I. I. (2006). Evaluasi variasi genetik tiga ras ikan gurame (Osphorenemus Gouramy) dengan metode isozyme. Jurnal Riset Akuakultur, 2, 51-57.

Nuryanto, A., Amalia, G., Khairani, D., Pramono, H., \& Bhagawati, D. (2017a). Molecular Characterization of Four Giant Gourami Strains from Java and Sumatera. Presented in $2^{\text {nd }}$ International Conferencson Life Sciencesand Biotechnology, Jember August 7-8, 2017.

Nuryanto, A., Pramono, H. \& Sastranegara, M. H. (2017b). Molecular identification of fish larvae from East Plawangan of Segara Anakan, Cilacap, Central Java, Indonesia. Biosaintifika: 
Journal of Biology and Biological Education, 9(1), 33-40.

Nuryanto, A., Solihin, D.D., Soedharma, D., \& Blohm, D. (2007). Molecular phylogeny of giant clams based on mitochondrial DNA cytochrome $\mathrm{c}$ oxidase I gene. HAYATI Journal of Biosciences, 14(4), 162-166

Pegg, G. G., Sinclair, B., Briskey, L., \& Aspden, W. J. (2006). MtDNA barcode identification of fish larvae in the southern Great Barrier Reef, Australia. Scientia Marina, 70(S2), 7-12.

Pepe, T., Trotta, M., Di Marcio, I., Cennamo, P., Anastasio, A., \& Cortesi, M. L. (2005). Mitochondrial cytochrome $b$ DNA sequence variations: an approach to fish species identification in processed fish products. Journal of Food Protection, 8(2), 421-425.

Pereira, L. H. G., Hanner, R., Foresti, F., \& Oliverira, C. (2013). Can DNA barcoding accurately discriminate megadiverse Neotropical freshwater fish fauna? BMC genetics, 14(1), 20.

Perez, G. A. C., Rican, O., Orti, G., Bermingham, E., Doadrio, I., \& Zardoya, R. (2007). Phylogeny and biogeography of 91 species of heroine cichlids (Teleostei: Cichlidae) based on sequences of the cytochrome $b$ gene. Molecular Phylogenetics and Evolution, 43(1), 91-110.

Predices, A., Cunha, C., \& Coelho, M. M. (2004). Phylogenetic structure of Zacco platypus (Teleostei, Cyprinidae) populationson the upper and middle Chang Jiang(= Yangtze) drainage inferred from sytochrome b sequences. Molecular Phylogenetics and Evolution, 31(1), 192-203.

Rozas. J., Sánchez-DelBarrio, J. C., Messeguer, X., \& Rozas, R. (2003). DnaSP, DNA polymorphism analyses by the coalescent and other methods. Bioinformatics, 19(18), 2496-2497.

Santos, S., Schneider, H., \& Sampaio, I. (2003). Genetic differentiation of Macrodon ancylodon (Sciaenidae,Perciformes) populations in Atlantic coastal waters of South America as revealed by mtDNA analysis. Genetics and Molecular Biology, 26(2), 151-161.

Sari, A. K., Nuryanto, A. \& Susanto, A. H. (2014). Karakterisasi beberapa strain gurami Osphronemus gouramy Lac. Menggunakan Marka RAPD. Scripta Biologica, 1(1), 113-116

Schneider, S., Roessli, D., \& Excoffier, L. (2000). Arlequin: A Software For Population Genetics
Data Analysis. Ver 2.000. Geneva: Genetics and Biometry Lab, Department of Anthropology, University of Geneva.

Setijaningsih, L., Arifin, O. Z., \& Gustiano, R. (2007). Karakterisasi tiga ras ikan gurame (Osphronemus gouramy Lac.) berdasarkan metode truss morfometriks. Jurnal lktiologi Indonesia, 7(1), 23-30.

Takehana,Y., Nagai, N., Matsuda, M., Tsuchiya, K., \& Sakaizumi, M. (2003). Geographic variation and diversity of the cytochrome $b$ gene in Japanese wild population of medaka. Oryzias latipes. Zoological Sciences, 20(10), 1279-1291.

Tamura, K., Stecher, G., Peterson, D., Filipski, A., \& Kumar, S. (2013). MEGA6: molecular evolutionary genetics analysis version 6.0. Molecular Biology and Evolution, 30(12), 2725-2729.

Thompson, J. G., Higgins, D. G., \& Gibson, T. J. (1994). CLUSTAL W: improving the sensitivity of progressive multiple sequence alignment through sequence weighting position-specific gap penalties and weight matrix choice. Nucleic acids research, 22(22), 4673-4680.

Tsigenopoulos, C. S., Rab, P., Naran, D., \& Berrebi, P. (2002). Multipleorigin of polyploidy in the phylogeny of southern African barbs (Cyprinidae) as inferred from mtDNA markers. Heredity, 88(6), 466-473.

Tzeng, W. N., Lin, H. R., Wang, C. H., \& Xu, S. N. (2000). Differences in Size and Growth Rates of Male and Female Migrating Japanese Eels in Pearl River, China. Journal of Fish Biology, 57(5), 1245-1253.

Walsh, P. S., Metzger, D. A., \& Higuchi, R. (1991). Chelex-100 as a medium for simple extraction of DNA for PCR Based Typing From Forensic Material. Biotechniques, 10(4), 506-513.

Yoon, Jong-Man., \& Park, Hong-Yang. (2002). Genetic similarity and variation in the cultured and wild crucian carp (Carassius carassius) estimated with random amplified polymorphic DNA. Asian-Australasian Journal of Animal Sciences, 15(4), 470-476.

Zieritz, A. \& Aldridge, D. C. (2009). Identification of ecophenotypic trends within three European freshwater mussel species (Bivalvia: Unionoida) using traditional and modern morphometric techniques. Biological Journal of the Linnean Society, 98(4), 814-825. 